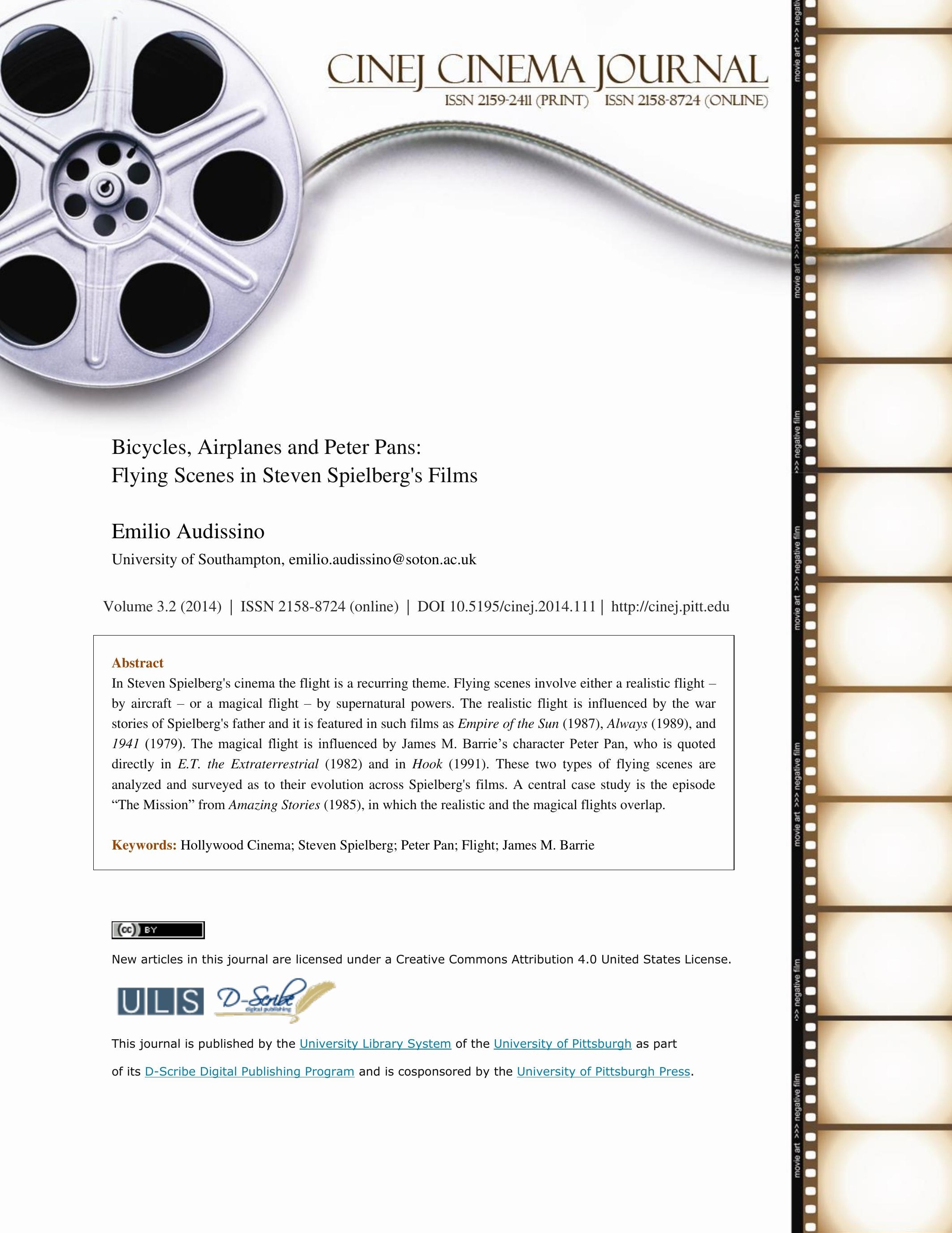


Bicycles, Airplanes and Peter Pans:

Flying Scenes in Steven Spielberg's Films

\section{Emilio Audissino}

I am absolutely fascinated and terrified by flying.

It is a big deal in my movies. All my movies have airplanes in them. You name the movie - they all fly. ${ }^{1}$

The sequence that epitomizes Steven Spielberg's work is perhaps the bicycle flight over the moon in E.T. The Extraterrestrial (1982). The director himself was so aware of it that he wanted that very image to be the logo of his production company, Amblin Entertainment. ${ }^{2}$ Indeed, flying sequences, aircraft and airplanes have been prominent since Spielberg's very first films. One of these, Fighter Squadron (1960), recreates air battles during World War II by blending close-ups of his young friends with archival footage. ${ }^{3}$ Ace Eli and Rodger of the Skies (1973, directed by John Erman) is based on his own story about a stunt pilot during the Twenties. Mysterious flying objects - Unidentified Flying Objects, actually - cross the skies of Close Encounters of the Third Kind (1977). The war farce 1941 (1979) is enlivened by an insanely clumsy pilot - Wild Bill Kelso, memorably played by John Belushi - an elaborate airplane chase along Hollywood Boulevard and an airplane-fetishist woman who gets aroused only when she is on board. An airplane flight is the regular starting point of the adventurous journeys in the Indiana Jones series - either willingly, as in Raiders of the Lost Ark where Dr Jones reaches his destinations of choice, Nepal and Egypt, by airlines; of unwillingly, as in Indiana Jones and the Temple of Doom where the Indian adventure begins serendipitously after 
a retaliation sky-jacking by the Chinese mobster Lao Che. ${ }^{4}$ The young protagonist of the war drama Empire of the Sun (1987) is obsessed with aeroplanes. A pilot is the lead of the love/ghost story Always (1989). ${ }^{5}$ The attempt of retrieving the ability to fly is the core metaphorical theme of Hook (1991). A helicopter flight starts the scary adventure on the island of Jurassic Park (1993), and provides the long-awaited rescue at the end. In Artificial Intelligence (2001) little robot David finally comes to meet the long-awaited Blue Fairy and fulfil his wish after a random trip with a flying machine. In Catch Me If You Can (2002), one of the many disguises of con artist Frank Abagnale Jr. is as an airline pilot. Moreover, when asked by then-President Bill Clinton to produce a short film to be featured at the 1999 New Year's Eve Millennium Gala in Washington D.C. to celebrate the history of the United States of America in the closing $20^{\text {th }}$ century, Spielberg dedicated the last section of his American Journey to "Technology and Flight," acknowledging flight as one of the biggest human achievements in the passing century. ${ }^{6}$

Flight is a patently recurrent theme in Spielberg's cinema. In the following pages, we will classify such recurrences into two classes, the magical flight and the realistic flight. The magical flight is rooted in a fairy tale, bigger-than-life context and such flight is made possible by some supernatural or extraterrestrial magic power; the realistic flight, instead, is presented in a realistic situation where flight can be achieved by technology and proper machinery, i.e. aircraft. The case study will be the Spielberg episode of the Amazing Stories feature film (1985), The Mission. 


\title{
Realistic Flight
}

The origin of Steven's fascination for airplanes and flight technology can be traced back to Arnold Spielberg, his father, and his tales and memories of service in the US Air Force in WWII.

\begin{abstract}
I'm closer to the '40s personally than I am to the ' 80 s. I love that period. My father filled my head with war stories - he was a radioman on a B-25 fighting the Japanese in Burma. I have identified with that period of innocence and tremendous jeopardy all my life. I collect documentaries, and I think I have every one made on that period. It was the end of an era, the end of innocence, and I have been clinging to it for most of my adult life. [...] I like the period because it was naïve and it was somewhat innocent and it represents the growing pains of the $20^{\text {th }}$ century. And it's a very fertile time for movie stories. [...] I think that World War II is the most significant event of the last 100 years; the fate of the Baby Boomers and even Generation X was linked to the outcome. ${ }^{7}$
\end{abstract}

From a child's point of view and from an American perspective the Air Force and its aircraft were the "Good guys" fighting the Nazis, the "Bad guys", in order to free the world from Evil. World War II, the "Good War", had been the archetypical Good-versus-Evil fight, before that the destruction of Hiroshima and Nagasaki and the intrigues of the Cold War made the border more blurred and greyish. Many of Spielberg's films, besides featuring airplanes, are set around the World War II years. The above-mentioned 1941, each film of the first Indiana Jones Trilogy, Saving Private Ryan (1998), ${ }^{8}$ and even in the contemporary Close Encounters of the Third Kind, we find pilots from that very period among the people abducted by the UFOs. In the harsh historical drama Empire of the Sun - a story about a boy who is split from his family during the Japanese invasion of Shanghai and is forced to face the atrocities of war and 
captivity - the only lyrical moments are those where little Jim, who is very fond of airplanes, ${ }^{9}$ sees one in the sky: "On the one hand there are hardships, deprivation and death experiences [...], on the other hand there is a tenderly cherished dream, that of flight - Spielberg's famous leitmotiv - that every now and then bursts into Jim's tough daily routine as airplanes rumbling in the sky, toy gliders landing at his feet..."10

For Jim, imprisoned in a Japanese concentration camp, they represent the dream of flying far and away from there, which is the only hope he can live on. When the US Air Force starts to bomb the camp in order to scatter the Japanese troops, Jim cheers and hails his saviors careless of the danger of staying exposed during the explosions. When food capsules are dropped, like manna from Heaven, John Williams's music score underlines the religious overtones of the moment with the choral piece Exsultate Justi from Psalm 33. US airplanes are "the good guys", the rescuing angels. However, in his other famous World War II drama, Schindler's List, quite fittingly the airplanes are absent, as they actually were: no airplane flew over Europe to bomb and cut the railways to the concentration camps so as to stop the death trains.

\section{Magical Flight}

A little longer explanation is needed to uncover the meaning of the magical flight. In Spielberg's cinema, flight as a personal supernatural power takes inspiration from James Matthew Barrie's famous literary creature, Peter Pan. Peter Pan is a central reference in Spielberg's cinema: "I am also Peter Pan. I've always been Peter Pan. [...] I've always had a strong affinity with that character. ${ }^{12}[\ldots]$ My mom read Peter Pan to me when I was, I guess, 
three-years-old. When I was eleven-years-old, I, along with other kids, directed a shortened version of James Barrie's Peter Pan in my elementary school..."13

As a matter of fact the two films where flight is most prominent, Hook and E.T., are both explicitly linked to Peter Pan. The former is a sequel to Barrie's book, while the latter features a direct quotation, in the scene where the mother reads a meaningful passage of the very novel to little Gertie - as we shall see below. Asked on which quality is the most appealing of the Peter Pan myth, Spielberg answers: "It's actually flying. To me, anytime anything flies, whether it's Superman, Batman, or E.T., it's going to be a tip of the hat to Peter Pan. Peter Pan was the first time I ever saw anybody fly. Before I saw Superman, before I saw Batman, and of course before I saw any superheroes, my first memory of anybody flying is in Peter Pan."14

To Spielberg, Peter Pan equates to flying. So, we must take a step backwards: What is the meaning of flight in Barrie's work? Here is a passage from the book: "'I say, Peter, can you really fly?' Instead of troubling to answer him Peter flew round the room, [...] 'I say, how do you do it?' [...] 'You just think lovely wonderful thoughts,' Peter explained, 'and they lift you up in the air.",15

In Barrie's book, the fuel that makes flying possible is happy thoughts, since happy thoughts make you feel weightless. But there is more: “... the moment you doubt whether you can fly you cease for ever to be able to do it."16 Another requirement to achieve flight is to believe that a supernatural, magical thing such a man flying can actually occur. Who meets both requirements? Those who still have happy thoughts and imagination are the children, and this is why they are able to fly. Here is a revealing dialogue between an adult Wendy and her little daughter: 
"I don't think I see anything to-night," says Wendy [...] "Yes, you do, "says Jane, "you see when you were a little girl." "That is a long time ago, sweetheart," says Wendy. "Ah me, how time flies!" "Does it fly," asks the artful child, "the way you flew when you were a little girl?" "The way I flew! Do you know, Jane, I sometimes wonder whether I ever did really fly." "Yes, you did." "The dear old days when I could fly!" "Why can't you fly now, mother?" "Because I am grown up, dearest. When people grow up, they forget the way." "Why do they forget the way?" "Because they are no longer gay and innocent and heartless. It is only the gay and innocent and heartless who can fly." 17

Adults cannot fly any longer because they have lost their imagination, innocence and their happy thoughts. The moment in which Peter Pan finds out that his friend Wendy is grown-up and is not able to come with him to Neverland again is depicted as a tragic scene:

Wendy was sitting on the floor, very close to the fire so as to see to darn, for there was no other light in the nursery; [...] Then the window blew open as of old, and Peter dropped on the floor. He was exactly the same as ever, and Wendy saw at once that he still had all his first teeth. He was a little boy, and she was grown up. She huddled by the fire not daring to move, helpless and guilty, a big woman. "Hullo, Wendy," he said, not noticing any difference, for he was thinking chiefly of himself; [...] "Hullo, Peter," she replied faintly, squeezing herself as small as possible. Something inside her was crying "Woman, woman, let go of me." [...] "Peter," she said, faltering, "Are you expecting me to fly away with you?" "Of course; that is why I come." [...] "I can't come," she said apologetically, "I have forgotten how to fly." "I'll soon teach you again." "O, Peter, don't waste the fairy dust on me." She had risen. And now at last a fear assailed him. "What is it?" he cried, shrinking. "I will turn up the light," she said, "and then you can see for yourself." For almost the only time in his life that I know of, Peter was afraid. "Don't turn up the light," he cried. She let her hands play in the hair of the tragic boy. She was not a little girl heart-broken about him; she was a grown woman smiling at it all, but they were wet smiles. Then she turned up the light, and Peter saw. [...] "What is it?" he cried again. She had to tell to him. "I am old, Peter. I am ever so much more than twenty. I grew up long ago." "You promised not to!" "I couldn't help it..." 
A question is in order now: Why flying? What is the prime motivation that drove Peter and should drive children to fly? Here is another telling passage. Wendy asks Peter about his age and his parents: “"Wendy, I ran away the day I was born.' [...] 'It was because I heard father and mother,' he explained in a low voice, 'talking about what I was to be when I became a man.' He was extraordinarily agitated now. 'I don't want ever to be a man,' he said with passion. 'I want always to be a little boy and have fun. So I ran away to Kensington Gardens and lived a long long time among fairies."

How did Peter run away? By flying, of course: "Well, Peter Pan got out by the window, which had no bars. Standing on the ledge he could see trees far away, which were doubtless the Kensington Gardens, and the moment he saw them he entirely forgot that he was now a little boy in a night-gown, and away he flew, right over the houses to the Gardens. It is wonderful that he could fly without wings, but the place itched tremendously, and - and perhaps we could all fly if we were as dead-confident-sure of our capacity to do it as was bold Peter Pan that evening", ${ }^{20}$

Given these premises, what is flight for Spielberg? "To me," he answers, "flying is synonymous with freedom and unlimited imagination..."21 So, flight is a symbol of escapism which sounds rather obvious - but a particular one. It is the means by which one can escape from growing up, from losing the joy and lightheartedness of childhood, from getting old, and from dying. Therefore flight, as opposed to adulthood, is also a symbol of childhood, which is notoriously another main theme in Spielberg's cinema. ${ }^{22}$

Close Encounters of the Third Kind is about a childlike man, Roy, who witnesses an UFO apparition and as a consequence he becomes obsessed with getting in touch with the extraterrestrial visitors. In spite of everyone - his family and friends, the fellow adults who, 
thinking he is insane, desert him - he stubbornly endures in his quest. He keeps on believing that a meeting is possible - "This means something. This is important," Roy continuously repeats - until he finally not only gets in touch with the aliens but eventually succeeds in flying away with them on their spaceship. It is a Peter Pan-like flight of a childlike man who is still able to believe he can fly despite everyone saying he cannot. The Peter Pan-like quality of this flight is evident in the film's finale when the people abducted by the extraterrestrials decades before disembark the spaceship to return to their home. They look exactly the same as when they left, having not grown old, as if they had lived in Peter Pan's world.

As to E.T. The Extraterrestrial, it is "one of the best essays on the inattention to children on the part of adults, or even on the irreducible difference/conflict between these two worlds." ${ }^{23}$ The adults see E.T. as an object to be studied and want to use him; the children see him as one of them, a friend to be loved and helped. When the alien and his earthling friends are pursued by the police with their cars and weapons, the children keep on believing that miracles can happen and indeed they magically fly away on their bicycles: quoting Barrie again, “...we could all fly if we were as dead-confident-sure of our capacity to do it as was bold Peter Pan..." ${ }^{24}$ Moreover, when E.T. is dying, the adults and their science fail to save him; the children and their faith in miracles make the resurrection possible. The quotation from Barrie's book in E.T. is now clear and stands out as a statement of poetics on Spielberg's part. In an intimate scene Gertie's mother reads her a passage from Peter and Wendy whose subjects are the magical power of imagination and the importance of believing. Tinkerbell, Peter Pan's fairy friend, is dying: "She [Tinkerbell] was saying that she thought she could get well again if children believed in fairies. [...] 'If you believe,' he shouted to them, 'clap your hands; don't let 
Tink die.' [...] Many clapped. [...] Tink was saved." ${ }^{25}$ The children still believe in fairies, they believe in E.T., and this makes the miracle possible.

\section{Flying - Both Realistically and Magically: 'The Mission'}

Both ideas of flight, that of human technology inspired by the Air Force tales and that of imagination power linked to Peter Pan, are interwoven in The Mission, a 40-minute episode written and directed by Spielberg for the 1985 TV show Amazing Stories. The setting is the European war front during World War II and the film is about a US Air Force team during their last bombing mission before discharge. The gunner, Jonathan, is a newly-wed and about to become a father. He has plans to get a job at Disney Studio, since he is an excellent cartoonist and, as everyone says, has the gift of imagination. During the flight the team is attacked by a German airplane. They fight back and shoot it down, but during its explosion one of the motors of the Nazi bomber hits the side of the US plane and gets soldered on the door of the belly turret, Jonathan's station. The young gunner is trapped inside and the only way to get him out is to cut the metal from the outside once the airplane has landed. Tragically, during the clash, the landing gear also got seriously damaged. The captain, although anguished and frustrated, cannot do anything but get ready for a belly landing which will crush Jonathan to death. At the climatic point, Static, the radio operator, pulls himself together and decides to give Jonathan a faster and better death by shooting him. So far, the situation is that of a realistic war drama, with somber brownish cinematography, very detailed art direction, from the uniforms and the cabin instrumentation to the vintage Betty Grable pin-up picture, highly knowledgeable technical references in the dialogue, and very harsh and realistic decisions to be taken. Suddenly, Peter Pan blows in for a fairy-tale happy ending. As a last ditch, Jonathan decides to 
use his best gift: imagination. He keeps on believing in a miracle and begins to envision it: on his drawing pad, he starts to sketch the bomber with a pair of Disney-like wheels in landing position. Then when the tarmac is practically underneath them, he asks the captain to try and push the landing gear release button once more. Although skeptically, the captain grants Jonathan's last wish and, to everyone's surprise, a pair of yellow cartoonish wheels pops out magically, just seconds before a shaken Static renounces the idea of "euthanasia" since he has no heart to shoot his friend. After a smooth landing Jonathan is rescued, still alive thanks to his faith and imagination. The film is about both realistic and magical flight, and a strong example of the importance of believing and the power of imagination in Spielberg's cinema.

\section{Evolution of the Flying Theme}

The evolution of the flying theme has been greatly influenced since September, $11^{\text {th }}$ 2001, when airplanes in flight were used as weapons to destroy the Twin Towers in New York City. Coincidentally, the fascination for flying objects almost completely disappeared in Spielberg's subsequent films. The Terminal (2004) is a bitter comedy about a stateless eastEuropean traveler who is trapped in JFK airport because of homeland security reasons following the USA Patriot Act. ${ }^{26}$ Although set in an airport, there are no images of flight at all, the airport itself being a prison, a symbolic Purgatory where the "alien" is caged. War of the Worlds (2005) is the first Spielberg film to portray cruel and warlike extraterrestrials, and it is an open metaphor of the 9/11 attacks, including the ghastly relics of a wrecked airplane, strikingly reminiscent of the United Airlines 93 which crashed in a Pennsylvania field.

"Would you have made the film if September 11 had not happened?" "Probably not. Wells' novel has been made into a film several times, notably always in times of 
international crisis: World War II had just begun when Orson Welles terrified millions of Americans with his legendary radio play version, the headlines were dominated by reports on Hitler's invasion of Poland and Hungary. When the first screen version came into the movie theaters in 1953, the Americans were very afraid of a nuclear attack by the Soviet Union. And our version also comes at a time when Americans feel deeply vulnerable."27

Munich (2005) is a political thriller about the Palestinian terrorist killing of Israeli athletes during the 1972 Olympic Games and the consequent vengeance of Mossad agents. In the climactic scene on the tarmac of the Munich airport, the terrorist raid ends with a ferocious gunfight in which all the Palestinian terrorists and Israeli hostages die, the helicopter turned from a flying machine into a death trap.

As to magical flight, the evolution was triggered the moment Spielberg became a father in 1985, and is presented clearly in Spielberg's personal rendition of Peter Pan: Hook. The film is about Peter Banning, a workaholic yuppie-style lawyer. During a visit to his old foster mother Wendy in London, Peter's children are kidnapped by one Captain James Hook. Shocked by the abduction, Peter is challenged by Wendy to go back to his childhood memories: strangely enough, he cannot recall anything, his childhood having seemingly never existed. Wendy finally reveals the truth: he was Peter Pan and has forgotten it because he has grown up. To save his children, Peter has to retrieve his own old self, go back to Neverland, and face Captain Hook. And there is only one way to do that and rescue the kids: Peter has to learn to fly again. As Franco La Polla puts it: "The metaphor of the ability to fly - lost and hard to retrieve - is a good one and very important, because it is not only perfectly fitting to the storyline, but it helps clarify the centrality and even the meaning of this theme in Spielberg's entire filmography." 28 
Flight is childhood itself fueled by the power of imagination, the authenticity of emotions, the sentimental openness to wonders, and an unbiased and uncorrupted view on life and the world. This childlike pureness hardly survives when one grows up, since the world requires very practical decisions and a realistic, if not cynical, point of view. In Hook, this case is stated outstandingly, as even Peter Pan, the boy who wouldn't grow up, eventually does grow up and in the worst way possible. Peter Banning "killed" his former Peter Pan-self in order to conform to the adult world. This repression is so important that it engenders a very meaningful neurosis: the fear of flying, the fear of heights, and the unmotivated unwillingness to visit old Wendy in London - a journey back to his roots, to Peter Pan's birthplace. The process of retrieval starts when the unwanted trip to London takes place and, of course, involves an intercontinental flight where a frightened Peter Banning has to deal with his neurotic fears on an ominous Pan Am aircraft, whose captain has the voice of Captain Hook. ${ }^{29}$

However, Hook is not just another statement on Spielberg's part about the importance of preserving childhood and the "ability to fly" but a landmark film in his cinema, since its final message is about the necessity to mediate between childhood and adulthood, between childlike escapism and mature commitment to reality. Both conditions are important and should be harmoniously present in a fully developed person. In a scene, Peter Banning is desperately searching for a happy thought that could help him fly, but can find none until he discovers that his happiest thought ever is the day he became a father. His lost ability to fly and his repressed childhood are thus retrieved through fatherhood. When Banning finally saves his children, he decides not to stay in Neverland to play with the Lost Boys - as Close Encounters protagonist and the younger Spielberg would have done ${ }^{30}-$ but goes back to the real world to 
be a better man and a better father. "There's nothing I love more than making movies, but now there's another kind of love. If I had to give it up for my son, I really believe I would."31

The film likely closes the first period in Spielberg's filmography, that of escapist fantasies. In the second period he has not renounced adventures and fantasies but has shown a stronger penchant for historical and realistic dramas. After Hook, Spielberg worked on a tandem of films exemplary of this new trend: the adventure blockbuster Jurassic Park and the holocaust black-and-white drama Schindler's List. In the latter, we witness cruelty even in the children - one German boy sadistically mimes an ominous cut-throat sign to some Jews being deported - and there is no way to escape the camps through imagination or happy thoughts nor solace, as happened in Empire of the Sun. In Jurassic Park, palaeontologist Alan Grant protests that he dislikes children as 'they're noisy, they're messy, they're expensive. They smell..." Eventually he will come to discover his fatherly side, as can be seen in the final closeup on the helicopter when he protectively looks on the sleeping kids.

This leads to a further, new interest emerging in the second period: fatherhood and the father-son relationship. This theme already emerged in Indiana Jones and the Last Crusade (1989), where the biggest novelty was having Indiana Jones forced to share the adventure with his estranged father, and in the process eventually reconcile with him. The theme is a central one in Catch Me If You Can, Munich and Indiana Jones and the Crystal Skull (2008). In Munich, the Mossad agent Avner is torn between his killer duties and the incompatibility of such deeds with being a father - a moral incompatibility on the one hand, and a safety incompatibility on the other: he is tormented by the worry that his family might be a target for retaliation. In Catch Me If You Can the igniting event that leads Frank to launch his criminal career is his parents' divorce, but even more so the absence of a fatherly figure in his life - his 
father is depicted as detached and unreliable. The absence of a fatherly figure is not something new in Spielberg's cinema - think of the family in E.T. where the father is completely absent, being in Mexico with his mistress. The difference is that the father-son reconciliation is now staged - at least in some vicarious form. This evolution can be explained, again, in autobiographical terms: Spielberg and his estranged father began to mend their relationship in mid 1990s and have recently reunited..$^{32}$ In Catch Me If You Can, if Frank embraced his illegal lifestyle because of the lack of a father, he eventually renounces it the moment he finds a fatherly figure in FBI agent Carl Hanratty - who in turns is divorced and in search of a fatherson relation. In Indiana Jones and the Kingdom of the Crystal Skull (2008) Indiana Jones himself discovers that he has a son and the most interesting part of the film is the path of reconciliation between the two - and with Marion, the mother and the heroine of Raiders of the Lost Ark. The film ends with a marriage - in the Hollywood tradition - and with Indiana Jones turned into a family father. Yet, when his son seizes Indiana's trademark fedora - as to inherit the adventurer role from the supposedly retired father - Indiana takes the hat back and dons it: being a father does not mean giving up adventures!

Childhood, defended and questioned, is a central theme in Spielberg's cinema and so is the flight, whose meaning is tightly linked to childhood. If we consider that for Spielberg cinema itself is closely related to his own childhood - both for the recurrent autobiographic references and for the fact that he began to try his hand at films at the age of 11 -in conclusion we can take a further step and draw another connection to close the survey: the flight can also be said to be a metaphor of cinema itself. Cinema is a magic instrument that allows traveling through space, time, dreams, and imagination. Watching a film is like taking a wonderful flight, whose pilot is the director. As Italian Spielberg scholar Franco La Polla states: "[As a 
director] in order to win your audience, you have to let them free: free to fantasize, to dream, to choose their own emotions and their own imaginary. The metaphor of flight in the whole cinema of Steven Spielberg has this meaning too: to hover and glide in the air, zooming and drifting to one's heart content like Peter Pan." ${ }^{33}$

\section{REFERENCES}

Lester D. Friedman, Brent Notbohm, eds., Steven Spielberg Interviews (Jackson: University of Mississippi Press, 2000).

Franco La Polla, Maria Teresa Cavina, eds., Spielberg su Spielberg (Turin: Lindau, 1995).

Philip Taylor, Steven Spielberg. The Man, His Movies \& Their Meaning, (London: B.T. Batsford, 1999, III ed.)

\section{ENDNOTES}

1) Steven Spielberg quoted in Lester D. Friedman, Brent Notbohm, eds., Steven Spielberg Interviews (Jackson: University of Mississippi Press, 2000), 153.

2) Similarly, the logo of Spielberg's distribution company - DreamWorks SKG - features a boy with a fishing rod sitting on a crescent moon.

3) Also known as Fighter Squad or Battle Squad: "I was inspired by those $8 \mathrm{~mm}$ Castle Films capsule documentaries of the Forties. They were in black-and-white and they had great gun camera shots of tracer bullets flying out and Messerschmidts catching fire and plunging to earth and tanks and trains exploding. I'd buy seven or eight of those films and pull out all the exciting shots and write a movie around them. The film stocks didn't match, so you could always tell when I was cutting to an actual stock shot." Steven Spielberg quoted in Friedman, Notbohm, Steven Spielberg Interviews, 57.

4) Airplane itineraries - marked by a travelling red line on a map, à la Old Hollywood - are featured in Raiders of the Lost Ark (1981), Indiana Jones and the Temple of Doom (1984), Indiana Jones and the Last Crusade (1989), Indiana Jones and the Kingdom of the Crystal Skull (2008).

5) "The film is about the beauty of flight, first of all. And even the supposed Paradise - or Pete's own Paradise, at least - is crossed by airplanes." Franco La Polla, Steven Spielberg (Milan: Il Castoro, 1995, II ed.), 109, my translation.

6) Images of airplanes flying and taking off are set to inspiring poetry reading and uplifting John Williams's music: http://www.kennedycenter.org/calendar/?fuseaction=composition\&composition $\_$id=2869, accessed May $5^{\text {th }} 2014$.

7) Spielberg quoted in Friedman, Notbohm, Steven Spielberg Interviews, 128-129, 136, 208.

8) Upon his acceptance speech on March, $21^{\text {st }}$ 1999, Spielberg dedicated his Academy Award for Best Direction to his father, acknowledging his inspirational contribution.

9) “As a child I used to build model planes [...] and I was attached to flying the way Jim is." Spielberg quoted in Friedman, Notbohm, Steven Spielberg Interviews, 128. 
10) La Polla, Steven Spielberg, 105, my translation.

11) Barrie introduced the now famous character in the 1902 novel The Little White Bird, whose chapters about Peter Pan were later republished - 1906 - under the title of Peter Pan in Kensington Gardens, following the wide success of the stage play Peter Pan or The Boy Who Wouldn't Grow Up - 1904. The novel version of the same play - Peter and Wendy - was published in 1911.

12) Spielberg quoted in Franco La Polla, Maria Teresa Cavina, eds., Spielberg su Spielberg (Turin: Lindau, 1995), 141, my translation.

13) Spielberg quoted in Friedman, Notbohm, Steven Spielberg Interviews, 152.

14) Ibid., 153.

15) J.M. Barrie, Peter and Wendy [1911], in Id. Peter Pan (London: Penguin Books, 2004), 33.

16) J.M. Barrie, Peter Pan in Kensington Gardens [1906], in Ibid., 171.

17) Barrie, Peter and Wendy, 147-148.

18) Ibid., 149-151.

19) Ibid., 27.

20) Barrie, Peter Pan in Kensington Gardens, 167.

21) Spielberg quoted in Friedman, Notbohm, Steven Spielberg Interviews, 153.

22) For further reading on childhood in Spielberg's cinema and its thematic connections with the "archetypical" figures of Peter Pan and Pinocchio, see Emilio Audissino, L'infanzia nel cinema di Steven Spielberg (Imperia: Ennepilibri, 2010).

23) Ezio Alberione, "E.T.: un'idea di cinema", in Ezio Alberione, ed., Incubi e meraviglie. Il cinema di Steven Spielberg (Milan: Unicopli, 2002), 150, my translation.

24) Barrie, Peter Pan in Kensington Gardens, 167.

25) Barrie, Peter and Wendy, 114.

26) On the USA Patriot Act, see http://epic.org/privacy/terrorism/hr3162.html, accessed May, $5^{\text {th }} 2014$.

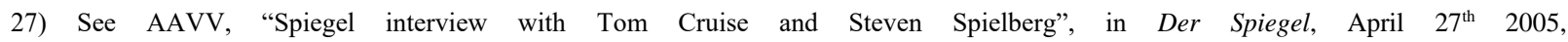
http://www.spiegel.de/international/spiegel/0,1518,353577,00.html, and Joseph Tirella, "Steven Spielberg 9/11 obsession", in msnbc.com, December $28^{\text {th }} 2005$, http://today.msnbc.msn.com/id/10549050, both accessed May, $5^{\text {th }} 2014$.

28) La Polla, Steven Spielberg, 117, my translation.

29) The voice in the cabin's sound system is clearly that of Dustin Hoffman, who plays Captain Hook.

30) "In Close Encounters I see the very sweet, idealistic odyssey of a man who gives up everything in pursuing his dreams or his obsessions. In 1997 I wouldn't have made Close Encounters the way I made it in 1977, because I have a family I would never leave.” Spielberg interviewed in Laurent Bouzereau's documentary The Making of Close Encounters of the Third Kind, Columbia Tristar Home Entertainment, 1997, DVD, DC 30020

31) Spielberg quoted in Philip Taylor, Steven Spielberg. The Man, His Movies \& Their Meaning, (London: B.T. Batsford, 1999, III ed.), 70.

32) See http://www.jewishjournal.com/hollywood/item/a_close_encounter_with_steven_spielbergs_dad_20120613 and http://www.hollywood.com/news/brief/42851381/steven-spielberg-opens-up-about-reconciliation-with-dad, accessed May, $5^{\text {th }} 2014$.

33) La Polla, Steven Spielberg, 110, my translation. 